\title{
The Relationship between Music Teacher Candidates' Academic and General Procrastination Tendencies and Test Anxiety
}

\author{
Asuman Seda Saracaloğlu ${ }^{1}$, Beste Dinçer ${ }^{1}$, Ceren Saygı Gerçeker ${ }^{2}$ \\ ${ }^{1}$ Department of Education Sciences, Adnan Menderes University, Aydın, Turkey \\ ${ }^{2}$ Department of Music, Adnan Menderes University, Aydın, Turkey. \\ Correspondence: Beste Dinçer, Adnan Menderes University, Department of Education Science, Aydın, Turkey.
}

Received: July 19, 2018

doi:10.11114/jets.v6i9.3456
Online Published: August 20, 2018

URL: https://doi.org/10.11114/jets.v6i9.3456

\begin{abstract}
The purpose of this research was to examine the relationship among the general, academic procrastination behavior of music teacher candidates, attitudes of test anxieties in terms of gender, grade levels and weekly study hours. The study was designed as relational correlational survey method. The sample of the study consisted of totally 73 teacher candidates who attended to $1^{\text {st }}$ and $4^{\text {th }}$ grades of Music Education Department in Education Faculty of Adnan Menderes University during the fall semester of 2016-2017 academic year. In the study, three kinds of data collecting instruments were used: General Procrastination Scale which was developed by Lay (1986) and The Turkish reliability and reality studies were done by Balkis (2003), Academic Procrastination Scale which was developed by Çakıcı (2003) and Westside Examination Anxiety Scale which was developed by Driscoll (2009) and Turkish validity and reliability studies were conducted by Totan \& Yavuz (2009). Results showed that men had more academic procrastination and lower text anxiety scores than women. Seniors were more likely to display both general and academic procrastination behaviours than freshmen. Significant and moderate positive correlations were found between academic procrastination and general procrastination tendencies $(\mathrm{r}=.50, \mathrm{p}<.05)$; and also between academic procrastination and test anxiety $(\mathrm{r}=.56$; $\mathrm{p}<.05)$.General procrastination tendency and test anxiety together predicted nearly half (45\%) of academic procrastination tendency.
\end{abstract}

Keywords: general procrastination, academic procrastination, music teacher candidates, test anxiety

\section{Introduction}

\subsection{Introduce the Problem}

The contents of academic scientific research in education and art show that studies have recently focused on affective dimension in general. The reasons for this trend might have arose from the emphasis made on behaviour change in the definition of education, the changes in understanding of learning and teaching, the desired student competencies, and the everyday living conditions. The increase in academic achievement both in terms of quality and quantity is desirable in education. However, learning may not always take place in the desired form. This may be related to several reasons: the readiness level of the learner may not conform to the topic to be learned, the teacher may not be knowledgeable in topics and teaching methods; learner may be reluctant and may not fulfill his / her duties. When the assigned tasks are not fulfilled, disruptions in the process of learning are inevitable. Learning procrastination is a reason for such disruptions in the program.

Learning procrastination is "postponing to fulfill a task, to take responsibility or to make a decision" (Kanchal, Hansen and Nutter, 2001 as cited in Akar, 2016: 115) and involves delaying responsibilities, decisions, or tasks that need to be done (Haycock McCarthy \& Skay, 1988: 317). Although the behaviour of procrastination initially gives a temporary feeling of comfort, after a while it creates negative feelings and thoughts, and causes feelings of anxiety, stress, failure and regret (Deniz, Traş \& Aydoğan, 2009: 610) so as time goes on it affects someone's performance negatively and directly violates his productivity.

As a type of procrastination, academic procrastination is typically defined as an irrational tendency to delay in the beginning and/or completion of an academic task (Senecal et al., 2003). In other words, academic procrastination is 
leaving homework, exam preparation, or perhaps a term paper that should be handed in at the end of the term to the very last minute (Saracaloğlu \& Göktaş, 2016). Whatever its type, procrastination is not merely a deficit of study skills or time management, it involves complex interaction of behavioral, cognitive and affective components. Evaluation anxiety, difficulty in making decisions, rebellion against control, lack of assertion, fear of the consequences of success, perceived averseness of the task and perfectionistic standards about competency were defined as some possible reasons for procrastination behavior (Solomon \& Rothblum, 1984: 503).

As it is stated that procrastination and academic procrastination are controversial issues, they are somewhat related to the fact that students do not have a study schedule and do not know how to become autonomous learners. If studying and learning processes are completed efficiently, the target can be reached easily. Indeed, the undesired behaviours or situations in education stem from student's lack of knowledge on what sort of a path he has to take in learning process. Therefore, the student may not feel the sense of achievement and therefore, he can develop negative attitudes about school and learning. As a result the academic procrastination behaviour reduces the quality of the education process and also affects exams that involve verbal or written feedback. When procrastinated academic work and duties are tried to be completed in the last moment, the test anxiety increases.

Test anxiety is expressed as a type of general anxiety and defined as a personal characteristic and variable (Spielberger \& Vagg, 1995) and the research shows that it can have both positive and negative impact on academic achievement. Morgan (1981: 114) argues that high anxiety may negatively affect learning whereas low level of anxiety makes learning difficult. A moderate level of anxiety can have positive impact on the learning process (as cited in Gençdoğan, 2006: 154). Students with high test anxiety may experience difficulties in reading and answering the questions or in choosing the words and expressions when expressing their thoughts. They may also face challenges in expressing their emotions and thoughts. The test anxiety may also prevent them from revealing their real potentials, they may fail to make the right profession choices or this may even cause drop-outs. Since the students with anxiety have difficulties in expressing their cognitive skills, they can choose the occupations that do not require competition (Ergene, 1994, as cited in Y1ldırım \& Ergene, 2003: 226). Among the reasons for the test anxiety; there may be family and school-related reasons. Family related issues may include the discipline that creates a negative environment at home and negative attitudes of mothers and fathers about the issue, etc., whereas school related issues include a negative classroom atmosphere, an educational atmosphere based on academic performance only, and negative teacher behaviours (Öner, 1989, as cited in Erözkan, 2004: 15). All these affect the educational process and create an inefficient learning experience and test anxiety.

So far, we have defined the variables and focused on how they are related to each other. In the literature there have been many domestic and international studies investigating the reasons and relations of procrastination behavior in different settings for years (Solomon \& Rothblum, 1984; Haycock et al., 1988; Onwuegbuzie, 2004; Balk1s, 2006). As one example related to this study for recent years, Küçük (2010) investigated the relationship between the test anxiety of music teachers, their achievement in instrument training and, self-esteem. The participants of the research were 66 music teacher candidates. The findings demonstrate that there is a significant relationship between test anxiety level and achievement in instrument training; and between test anxiety and self-esteem level. Özer \& Topkaya (2011) investigated the relationship between academic procrastination and test anxiety. The participants were 109 undergraduate students; the age of the sample group ranged between 17 and 29; there were 61 female and 48 male students. The findings show that there were no significant differences in terms of gender and academic procrastination but it was found out that women have more text anxiety than men and a significant relationship was found between fear of failure and test anxiety. Akar (2016) investigated the relation between general procrastination and studying approach of prospective teachers of elementary education. Correlation analysis results showed that significant relationships between study approach subscales and general procrastination subscales were found and the deep study approach has been shown to significantly predict the efficient use of time and superficial study approach significantly predicts procrastination. Also the studies related to the affective (emotional) areas of academic procrastinatio show that there is a negative relationship between the procrastination and responsibility, achievement attitude, and GPA while a positive relationship exists between prefractionation and, work avoidance, perfectionism and sense of accomplishment (van Eerde, 2003 \& Steel 2007; as cited in Özer and Altun, 2011: 46).

\subsection{The Importance of the Problem}

Life-long learning is becoming an important aspect and skill of education faculties because teachers also have the social good responsibility of enlightening the society. Especially music education differs from other departments in the Education faculty because it has its own elective courses (instrument training and voice training etc.) in addition to general electives. The accomplishment in the field is based on master-apprentice relationship in the courses. Musical and technical improvement can only be achieved with a disciplined daily practice. Therefore, it is very important that students keep up with their daily practices on time in order not to postpone their performances. When the literature is reviewed, no research that directly focused on the variables of procrastination, academic procrastination, test anxiety together were found related to merely music education department students. 


\subsection{The Purpose of the Research}

The overall purpose of this research is to investigate the relationship among music teachers' general and academic procrastination tendencies and behaviours and test anxiety.

The research seeks answer to following questions:

1) Do the general and academic procrastination tendencies, test anxiety of music teacher students significantly differ in terms of variables of gender?

2) Do the general and academic procrastination tendencies, test anxiety of music teacher students significantly differ in terms of grade levels?

3) Are the attitudes of general and academic procrastination tendencies, test anxiety of music teacher students significantly differ in terms of weekly study hours?

4) Are there any significant correlations among academic procrastination, general procrastination tendency and test anxiety variables?

5) When the general procrastination tendency, the attitudes of the test anxiety are taken together, do they significantly predict the music teacher students' tendency of the academic procrastination?

\section{Methods}

\subsection{Research Design}

The research is a descriptive study and employs a correlational survey model. Survey models are descriptive explaining a situation. Among these, correlational survey models aims to determine the degree of change or the degree of change between two or more variables (Karasar, 2005).

\subsection{The Study Sample}

The participants of this research are first-year and fourth-year 73 teacher candidates studying at Music Education department of Adnan Menderes University during 2016-2017 academic year. Since we were able to reach the entire research population, we did not use sampling. Accordingly, $43.8 \%$ of participants were women ( $\mathrm{N}=32)$ whereas $\% 56,2$ of participants were men $(\mathrm{N}=41)$. Likewise, \%42,5 of the participants were freshmen $(\mathrm{N}=31)$ while $\% 57,5$ were seniors $(\mathrm{N}=42)$.

\subsection{Data Collecting Instruments}

The research employed three data collections as illustrated below:

Academic Procrastination Scale: We used academic procrastination scale developed by Çakıcı (2003) to identify academic procrastination behaviours of students. The scale consists of 19 items (12 negative and 7 positive items). The items predominantly measure academic tasks of students (studying, preparing projects, exams). It is a five-point Likert-type scale based on belief (for example, very untrue of me, slightly true of me, somewhat true of me, true of me, very true of me). Cronbach alpha reliability coefficient of the scale for this research was .92 .

Procrastination Scale: Procrastination Scale was developed by Lay (1986) to measure the procrastination tendencies of students. The scale has only one dimension and 20 items. It is five-point Likert type scale. This scale has been adapted into Turkey by Balkis (2006). The Turkish adaptation has 15 items. The Cronbach alpha reliability coefficient of the scale for this research was .76.

West Side Test Anxiety Scale: This scale was developed by Driscoll (2009) and it was adapted into Turkish by Totan and Yavuz (2009). The scale has one dimension and 11 items. All the items are reverse coded. The high scores indicate that anxiety level is high whereas low scores mean that anxiety level is low. The scores of the scale ranges between 11 and 55. Cronbach alpha reliability coefficient of the scale for this research was .92 .

Also personal information form was used to collect demographic information about gender, class level and weekly study hours variables.

\subsection{Data Collecting Procedures}

After the permissions were received from both the developers of the scales and the dean of the faculty, the researcher collected the data by herself in lesson hours by explaining the importance of the study to make the students give truthful response. The university students completed the scales approximately 10-15 minutes.

\subsection{Data Analysis}

Firstly normality tests were done to find out whether the data was normally distributed or not. As the results show that three variables (gender, grade levels and weekly study hours) of the data were not normally distributed, Mann Whitney 
-U test was used to compare two independent groups (gender/year of study) and Kruskalwallis $\mathrm{H}$ test was used to compare more than two groups (weekly study hours). As the total scores were normally disturbed, Pearson correlation analysis was employed to explore the correlation among variables, and multiple regression analysis was performed to predict music teacher education students' academic procrastination in terms of procrastination tendency, test anxiety variables in total scores.

\section{Results}

\subsection{Findings Regarding the First Sub-problem}

The first sub-problem of the research is "Do the scores of general and academic procrastination of music teachers, test anxiety and, study and learning strategies show a significant difference according to gender?" The Mann Whitney-U test results for this sub-problem are presented below.

Table 1. Mann Whitney-U test results of general and academic procrastination, test anxiety scores in terms of gender variable

\begin{tabular}{|c|c|c|c|c|c|c|}
\hline & Group $\mathrm{N}$ & & & Mean Sum & $\mathrm{U}$ & $\mathrm{p}$ \\
\hline \multirow[t]{2}{*}{ General Procrastination } & Woman & 32 & 30,94 & 990,00 & 462,000 & ,031* \\
\hline & Man & 41 & 41,73 & 1711,00 & & \\
\hline \multirow[t]{2}{*}{ Academic Procrastination } & Woman & 32 & 32,50 & 1040,00 & 512,000 &, 109 \\
\hline & Man & 41 & 40,51 & 1661,00 & & \\
\hline \multirow[t]{2}{*}{ Test Anxiety } & Woman & 32 & 39,05 & 1249,50 & 590,500 & ,466 \\
\hline & Man & 41 & 35,40 & 1451,50 & & \\
\hline
\end{tabular}

When the general and academic procrastination scores, Mann Whitney-U test results of test anxiety and, study and learning strategies in terms of gender are analysed, significant difference can be seen in general procrastination tendency of male students $(\mathrm{p}=, 031 ; \mathrm{p}<.05)$ and in attitudes towards study and learning strategies of female students $(\mathrm{p}=.017 ; \mathrm{p}<.05)$. This result implies that male students are more likely to procrastinate and female students have positive attitudes towards the use of study and learning strategies. Although it is not statistically significant, it can be argued on the basis of mean scores that the male students have more academic procrastination and so lower text anxiety scores than women.

\subsection{Findings Regarding to Second Sub-problem}

The second sub-problem is "Do the scores of general and academic procrastinations, test anxiety and study and learning strategies show a significant difference in terms of year of study?" The Mann Whitney-U test results for this sub-problem are given below.

Table 2. Mann Whitney-U Test Results of general and academic procrastination, test anxiety scores in terms of grade levels

\begin{tabular}{|c|c|c|c|c|c|c|}
\hline & Group & $\mathrm{N}$ & $\begin{array}{l}\text { Mean } \\
\text { Rank }\end{array}$ & Mean Sum & $\mathrm{U}$ & $\mathrm{p}$ \\
\hline \multirow[t]{2}{*}{ General Procrastination } & $1^{\text {st }}$ year & 31 & 29,44 & 912,50 & \multirow[t]{2}{*}{416,500} & \multirow[t]{2}{*}{, $009 *$} \\
\hline & $4^{\text {th }}$ year & 42 & 42,58 & 1788,50 & & \\
\hline \multirow[t]{2}{*}{ Academic Procrastination } & $1^{\text {st }}$ year & 31 & 31,23 & 968,00 & \multirow[t]{2}{*}{472,000} & \multirow[t]{2}{*}{,046* } \\
\hline & $4^{\text {th }}$ year & 42 & 41,26 & 1733,00 & & \\
\hline \multirow[t]{2}{*}{ Test Anxiety } & $1^{\text {st }}$ year & 31 & 31,02 & 961,50 & \multirow[t]{2}{*}{465,500} & \multirow[t]{2}{*}{,038* } \\
\hline & $4^{\text {th }}$ year & 42 & 41,42 & 1739,50 & & \\
\hline
\end{tabular}

As table 2 suggests, significant differences can be seen in all variables between 1 st and $4^{\text {th }}$ year students (p>.05). In other words, $4^{\text {th }}$ year students are more likely to display both general and academic procrastination behaviours and also test anxiety than first year students. Seniors are less enthusiastic for learning so they have stronger tendency for academic and general procrastination behaviour along with test anxiety. This situation may be resulted from they have just gotten out of from the stressful university admission process and settled into a new institution with new identities as university students.

\subsection{Findings Related to Third Sub-problem}

The third sub-problem is "Do the scores of general and academic procrastinations, test anxiety and study and learning strategies show a significant difference in terms of weekly study hours? Kruskalwallis-H test for this sub-problem is given below. 
Table 3. Kruskalwallis-H Test Results of general and academic procrastination, test anxiety scores in terms of year of weekly study hours

\begin{tabular}{|c|c|c|c|c|c|c|}
\hline & Weekly study hours & $\mathrm{n}$ & Mean rank & $\mathrm{sd}$ & $\mathrm{X}^{2}$ & $\mathrm{p}$ \\
\hline \multirow[t]{5}{*}{ General Procrastination } & Less than one hour & 13 & 46,42 & \multirow[t]{5}{*}{4} & \multirow[t]{5}{*}{8,405} & \multirow[t]{5}{*}{0,78} \\
\hline & 1-3 hours & 19 & 40,03 & & & \\
\hline & 4-6 hours & 15 & 25,37 & & & \\
\hline & $7-10$ hours & 15 & 33,37 & & & \\
\hline & 11-15 hours & 11 & 41,45 & & & \\
\hline \multirow[t]{5}{*}{ Academic Procrastination } & Less than one hour & 13 & 57,92 & \multirow[t]{5}{*}{4} & \multirow[t]{5}{*}{21,134} & \multirow[t]{5}{*}{, $000 *$} \\
\hline & 1-3 hours & 19 & 40,13 & & & \\
\hline & 4-6 hours & 15 & 23,80 & & & \\
\hline & $7-10$ hours & 15 & 28,83 & & & \\
\hline & 11-15 hours & 11 & 36,00 & & & \\
\hline \multirow[t]{5}{*}{ Test anxiety } & Less than one hour & 13 & 54,58 & \multirow[t]{5}{*}{4} & \multirow[t]{5}{*}{13,773} & \multirow[t]{5}{*}{, $008 *$} \\
\hline & 1-3 hours & 19 & 37,13 & & & \\
\hline & 4-6 hours & 15 & 37,40 & & & \\
\hline & $7-10$ hours & 15 & 27,37 & & & \\
\hline & 11-15 hours & 11 & 28,59 & & & \\
\hline
\end{tabular}

As it's seen in Table 3, there are significant differences among academic procrastination and test anxiety scores and weekly study hours of students. As far as average scores are concerned, the students who study less than one hour in a week are seemed to have more academic procrastination tendency and test anxiety than others studying longer hours. In addition to these results to find the source of difference, Mann Whitney-U test is done for each variable and significant relations were shown in Table 4 and 5.

Table 4. Mann Whitney $U$ test results of Academic procrastination in terms of weekly study hours

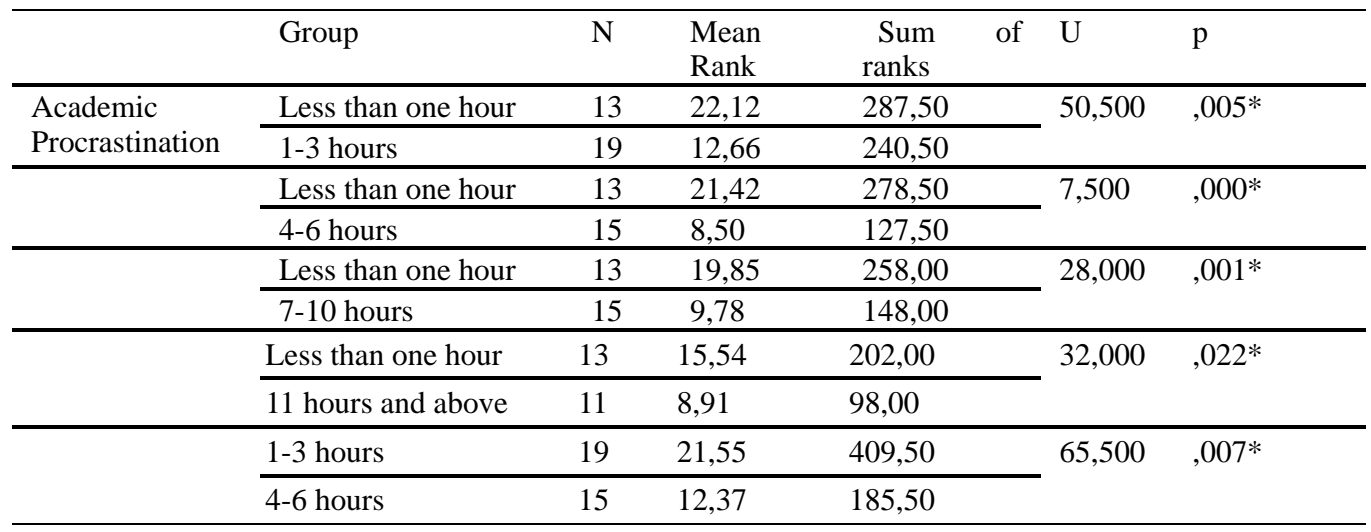

As table 4 suggests, five significant differences were observed between the students' academic procrastination tendency and weekly study hours. The students studying less than one hour in a week have more academic procrastination tendency than the students studying 1 hour and longer hours. In other words mean rank scores shows that as the students' weekly study hours increases, academic procrastination decreases.

Table 5. Mann Whitney U test results of test anxiety in terms of weekly study hours

\begin{tabular}{|c|c|c|c|c|c|c|}
\hline & Group & $\mathrm{N}$ & Mean Rank & $\begin{array}{l}\text { Sum of } \\
\text { ranks }\end{array}$ & $\mathrm{U}$ & $\mathrm{p}$ \\
\hline \multirow[t]{8}{*}{ Test Anxiety } & $\begin{array}{l}\text { Less than one } \\
\text { hour }\end{array}$ & 13 & 21,23 & 276,00 & 62,000 & ,018* \\
\hline & 1-3 hours & 19 & 13,26 & 252,00 & & \\
\hline & $\begin{array}{l}\text { Less than one } \\
\text { hour }\end{array}$ & 13 & 18,38 & 239,00 & 47,000 &, $020^{*}$ \\
\hline & 4-6 hours & 15 & 11,38 & 167,00 & & \\
\hline & $\begin{array}{l}\text { Less than one } \\
\text { hour }\end{array}$ & 13 & 19,92 & 259,00 & 27,000 &, $001 *$ \\
\hline & $7-10$ hours & 15 & 9,80 & 147,00 & & \\
\hline & $\begin{array}{l}\text { Less than one } \\
\text { hour }\end{array}$ & 13 & 16,04 & 208,50 & 25,500 &, $008 *$ \\
\hline & $\begin{array}{l}11 \text { hours and } \\
\text { above }\end{array}$ & 11 & 8,32 & 91,50 & & \\
\hline
\end{tabular}

Similar to previous results, four significant differences $(\mathrm{p}<.05)$ were observed between the students' test anxiety and 
weekly study hours in Table 5. The students studying less than one hour in a week have more test anxiety than the students studying 1 hour and longer hours. In other words mean rank scores shows that as the students' weekly study hours decreases, test anxiety increases. It can be said that as the students study more, they feel they are more capable of achieving the tests. Every time it's not the case; that is long study hours don't reflect the test scores directly but in music department students especially for the lessons requiring individual instrument performance, it can be said that the harder they study, the less they feel anxious about tests.

\subsection{Findings Related to Fourth Sub-problem}

In the fourth sub-problem of the research, the relationship between the academic procrastination and general procrastination tendencies, the scores of the test anxiety and the study and learning strategies were tested by pearson correlation analysis and the results are shown in Table 5.

Table 5. Pearson Correlation Analysis of general procrastination and academic procrastination, test anxiety and study and learning strategies scores

\begin{tabular}{|c|c|c|c|c|c|}
\hline \multirow{2}{*}{$\begin{array}{l}\text { Correlations } \\
\text { Pearson rho }\end{array}$} & & & $\mathrm{AP}$ & GP & TA \\
\hline & \multirow{3}{*}{$\begin{array}{l}\text { Academic } \\
\text { Procrastination } \\
\text { (AP) }\end{array}$} & $\begin{array}{l}\text { Correlation } \\
\text { Coefficient }\end{array}$ & 1 &, $501 * *$ &, $563 * *$ \\
\hline & & Sig. (2-tailed) & &, 000 &, 000 \\
\hline & & $\mathrm{N}$ & 73 & 73 & 73 \\
\hline & \multirow{3}{*}{$\begin{array}{l}\text { General } \\
\text { Procrastination } \\
\text { (GP) }\end{array}$} & $\begin{array}{l}\text { Correlation } \\
\text { Coefficient }\end{array}$ & ,501** & 1 & ,278* \\
\hline & & Sig. (2-tailed) &, 000 & &, 017 \\
\hline & & $\overline{\mathrm{N}}$ & 73 & 73 & 73 \\
\hline & \multirow[t]{3}{*}{$\begin{array}{l}\text { Test Anxiety } \\
\text { (TA) }\end{array}$} & $\begin{array}{l}\text { Correlation } \\
\text { Coefficient }\end{array}$ &, $563 * *$ & ,278* & 1 \\
\hline & & Sig. (2-tailed) & ,000 & 017 & \\
\hline & & $\overline{\mathrm{N}}$ & 73 & 73 & 73 \\
\hline
\end{tabular}

**. Correlation is significant at the 0.01 level (2-tailed).

*. Correlation is significant at the 0.05 level (2-tailed).

As table 5 shows, there is a moderate positive correlation between academic procrastination and general procrastination tendencies $(\mathrm{r}=.50, \mathrm{p}<.05)$. Likewise, there is a moderate and positive procrastination between academic procrastination and test anxiety $(r=.56 ; p<.05)$. In other words, as the academic procrastination tendencies of students increase, so do their general procrastination tendencies and test anxiety. Additionally, there is a low but positive correlation between general procrastination and test anxiety $(\mathrm{r}=.278, \mathrm{p}<.05)$.

\subsection{Findings Related to Fifth Sub-research Problem}

Table 6. Multiple Regression results of Music teacher candidates' academic Procrastination behavior together with independent variables

\begin{tabular}{|c|c|c|c|c|c|c|c|c|c|}
\hline & $\mathrm{B}$ & Std. Hata & $\beta$ & $t$ & $p$ & Tolerance & VIF & CI & $\% 95$ GA \\
\hline (Fixed) & 13,203 & 6,135 & & 2,152 & ,035 & & & 1,000 & $0,966 / 25,439$ \\
\hline Test Anxiety & 0,635 & 0,128 & ,459 & 4,950 & 000 & ,923 & 1,084 & 7,274 & $0,379 / 0,890$ \\
\hline General Procrastination & 0,558 & 0,138 &, 374 & 4,036 &, 000 & ,923 & 1,084 & 10,279 & $0,282 / 0,833$ \\
\hline $\begin{array}{l}\text { Academic Procrastination } \\
\text { procrastination }\end{array}$ & $=13,20$ & ,635xTest & nxiet & $+0,558 x$ & General & $\begin{array}{l}\mathrm{R}^{2}=0,446 \quad / \quad \mathrm{Ad} \\
\mathrm{R}^{2}=0,43\end{array}$ & $(2,7)$ & 121 & \\
\hline
\end{tabular}

Multiple regression analysis was conducted to determine the extent to which levels general anxiety and test anxiety were explained academic procrastination behavior. According to multiple regression results, the model is seemed to be avaliable.

It was determined that the model constructed according to the multiple regression analysis is valid as a whole $\left(\mathrm{F}_{(2,70)}=28,121 ; \mathrm{p}<0,000\right)$ and that independent variables account for $45 \%$ of the total variance explained for academic procrastination $\left(\mathrm{R}^{2}=0,446\right)$. When the parameters related to the multiple regression model are examined, the standardized regression coefficients $(\beta)$ indicate the order of significance over the test anxiety of the predictive variables; $(\beta=, 459, \mathrm{t}=4,950, \mathrm{p}=, 000, \mathrm{p}=0,00)$, and general procrastination $(\beta=, 374 ; \mathrm{t}=4,036 ; \mathrm{p}=0,00)$ respectively. When the results of the t-test on the significance of the regression coefficients are examined, it is seen that the two variables discussed also have a significant $(\mathrm{p}=.000 ; \mathrm{p}<.005)$ predictive effect on academic procrastination behaviour.

According to the results of regression analysis, the regression equation (mathematical model) related to the prediction of academic procrastination is given as: Academic Procrastination $=13,203+0,635 \times$ Test Anxiety $+0,558 \mathrm{x}$ General procrastination. 


\section{Discussion}

In the literature, many studies can be found investigating the relationship between academic procrastination behaviour and different variables. However, in this study, variables such as gender, grade levels, weekly study hours, test anxiety were included to explore to what extent such variables are effective.

The results of the research show that male students are more likely display general and academic procrastination behaviours than female students. On the other hand, female students have more positive attitudes towards study and learning strategies. This suggests that there is a gender difference in terms of procrastination behaviour. Some studies investigating the relationship between academic procrastination behaviour and gender demonstrate different results. Yet, some of the research also shows that men are more likely to demonstrate academic procrastination behaviours. For example, Balkis, Duru \& Duru (2006) argues that the levels of male students' tendency to procrastinate the academic tasks are higher than those of female students' tendencies. Uzun Özer, Demir \& Ferrari (2009) reported that undergraduate male students had significantly higher levels of academic procrastination than female students. Likewise, Pala, Akyıldız \& Bağc1 (2011) also suggests that the academic procrastination behaviours of male students were higher than female students. Similarly, Çıkrıkçı \& Erzen (2016) found in their meta-analysis work that that gender was an important variable on academic procrastination behaviour and showed that academic procrastination tendencies of male students are higher than female students. Khan, Arif, Noor, \& Muneer (2014) investigated gender differences in academic procrastination behavior in their study and found that male students procrastinate more than female college and university students. Balkis \& Duru (2017) reported that male students had higher level academic procrastination and lower level of academic performance and academic life satisfaction. Although it is not clear cuts, the reason why men tend to show more procrastination may be related to the social construction that girls are seen more hardworking and responsible than boys. Such a cultural stereotype may be thought to shape the gender roles and the responsibilities of men and women. Hess, Sherman, \& Goodman (2000) found in their study that evening news was as a predictor of academic procrastination with 107 US undergraduate students. If it is looked at the study result from this perspective, it can be explained to some extend why men are more at risk for academic procrastination in music department. Although it can't be generalized, men tend to stay outside later hours than women in Turkish culture. Furthermore, male students in music department usually work in entertainment sector at late hours to earn their pocket money. That situation may also cause an unhealthy lifestyle in which evening less and procrastination occur.

This research also focused on the variable of 'grade levels. The results show that seniors are more likely to display general and academic procrastination tendencies than freshmen. Likewise, Çelik \& Odac1 (2015) demonstrated that academic procrastination behaviour had a significant difference in terms of year of study and that third year students displayed more academic procrastination behaviours than the second year students. McCown \& Roberts (1994) also revealed that $19 \%$ of students in the first year showed academic procrastination behaviour, while students in the fourth grade showed an increase in procrastination behaviours and 31\% of them showed academic procrastination behaviours. Similarly Karabıyık Çeri, Çavuşoğlu \& Gürol (2015) concluded that there was a meaningful difference between the level of academic deferment of the students attending the fourth grade and the students attending the third grade. It can be said that the students who read in the fourth grade tend to show more academic procrastination behavior than the students who study in the third grade. Although the sample group is different, Yayc1 \& Düşmez (2016) also found that the age variable influenced procrastination and $12^{\text {th }}$ grade students showed more procrastination behaviours compared to the other grades $(9,10,11)$. Onwuegbuzie (2004) noted that it is possible that graduate students procrastinate more for different reasons than do undergraduates in a different point of view. This shows that new comers to the university are more enthusiastic in terms of systematic studying whereas within the years they lose the discipline and enthusiasm towards studying. In addition, it can be interpreted that the increase in anxiety levels of final year students may affect the attitudes towards learning and working negatively.

The third variable related to the academic procrastination tendency is the test anxiety. Test anxiety has a significant correlation with the academic and general procrastination behaviours of students in this study. For instance, Özer \& Topkaya (2011) pointed out in their research on academic procrastination and test anxiety that there was a significant correlation between the fear of failure and test anxiety $(\mathrm{r}=.34)$. Balkıs et al. (2006) showed that the academic procrastination tendency had a significant positive correlation with the negative attitudes toward learning, learning difficulties and concentration difficulties. The work of Kağan (2009) on university students show that there is a positive and significant correlation between academic procrastination and general procrastination whereas there is a weak significant and negative correlation between academic procrastination and anxiety. Onwuegbuzie (2004) also reported that individuals who experience increases in levels of statistics anxiety are more likely to postpone undertaking statistical activities and assignments (e.g. writing term papers, studying for examinations, and keeping up with the weekly readings) due to task averseness. As Hussain \& Sultan (2010) stated procrastination has negative side effects on the learning of students such as causing failure or fear of failure in the examinations resulting in depression and anxiety 
because it lowers their morale. Therefore it can be argued that whatever the kind of procrastination is, it is clear that it slows down the performance of students making them careless, lazy, passive and academically stagnant $\&$ irresponsible. As a result they can not complete their studies and they find themselves in a negative vicious cycle to start or complete the work in an expected time.

Finally, the regression model shows two variables together (test anxiety and general procrastination tendencies) predict academic procrastination and explain almost $50 \%$ of the variance. There are not any studies directly related to our study but similar studies were discussed to give clues about procrastination behaviour. Şirin (2011) suggested that the only variable that predicted academic procrastination was general procrastination behaviour. As differs from our research Tan et al. (2008) indicates that self efficacy was a strongly and negatively related to procrastination whereas test anxiety and academic stress did not emerge as significant factors explaining procrastination behaviour. As a result of Çakır et al. (2014)'s study it is seen that there is a positive relation between academic procrastination and school burnout or academic burnout and it explains 37\% of procrastination behaviour in regression model. Kagan (2009) in his study investigating university students' academic procrastination tendencies, found that the most powerful explanations of academic postponement were general postponement, time management and motivation. Saracaloğlu \& Göktaş (2016) reported that laziness, academic motivation, and fear of failure are significant predictors of academic procrastination. Academic procrastination has the highest correlations with reasons of academic procrastination; fear of failure, risk taking, and rebellion against control. Additionally, Akbay \& Gizir (2010) observed that academic motivation, academic self-efficacy and academic attributional style were the significant predictors of academic procrastination among university students.

As a summary when looking at the literature, it can be observed that the predictors of the procrastination behaviour can not be explained in only one factor because it has a diverse structure but in general as it was found in our study that general procreation and test anxiety effect procrastination behaviour in a direct manner.

\section{Suggestions}

The sampling group of this research was Music Education students at Fine Arts Education Faculty. The reason why we conducted this research with this group of students was that the number of graduates considerably decreased within the time and only three students graduated in 2017. Furthermore, lecturers in this department also note that students do not keep up with designated tasks. Therefore, one limitation of this research is that the research can be conducted with students in other departments. This research can also be strengthened by qualitative methodology.

The results show that fourth year students have more general and academic procrastination behaviour compared to first year students so semi-structured interviews can be used to elaborate on the reasons of such behaviours and may be elective courses attentive to effective studying and learning strategies of students can be introduced.

This research primarily looked at the variables of academic and general procrastination, test anxiety, study and learning strategies and the correlation between these variables. Further researches can expand the scope of the study and carry out a modelling study.

\section{Note}

This research is an improved form of the oral presentation which was presented in the 26th International Conference on Educational Sciences (ICES-UEBK. 2017) that was held between the dates of April 20-23, 2017 in Antalya in Turkey.

\section{References}

Akar, H. (2016). Analysis the relationship between general procrastınation and studying approach of prospective teachers at department of elementary education through structural equation modeling. Kilis University Journal of Social Sciences, 6(11), 111-135.

Akbay, S. E., \& Gizir, C. A. (2010). Academic procrastination among university students according to gender: the role of academic motivation, academic self-efficacy and academic attributional style. Mersin University Journal of the Faculty of Education, 6(1), 60-78.

Balkis, M. (2006). Relationship among teacher candidates' procrastination behaviors, thoughts and decision-making styles (Unpublished PhD Thesis), Dokuz Eylül Üniversity, İzmir.

Balkis, M., \& Duru, E. (2017). Gender differences in the relationship between academic procrastination, satifaction with academic life and academic performance. Electronic Journal of Research in Educational Psychology, 15(1), 105-125. https://doi.org/10.14204/ejrep.41.16042

Balkis, M., Duru, E., Buluş, M., \& Duru, S. (2006). Investigating university students' academic procrastination levels according to some variables. Ege University Education Faculty Journal, 2(7), 59-75. 
Çakıc1, D. Ç. (2003). Investigating high school and university students' general and academic procrastination (Unpublished Master Thesis), Ankara University, Ankara.

Çakır, S., Akçab, F., Fırıncı, K. A., \& Tulgarerd, S. (2014). The survey of academic procrastionation on high school students with in terms of school burn-out and learning tyles, Procedia - Social and Behavioral Sciences, 114(2014), 654-662, 1877-0428 doi: 10.1016/j.sbspro.2013.12.763 (4th World Conference on Psychology, Counselling and Guidance WCPCG-2013). https://doi.org/10.1016/j.sbspro.2013.12.763

Çelik, Ç. B., \& Odacı, H. (2015). Explanation of academic procrastianation by some personal and psychological variables. Hacettepe Universitersity Journal of Education, 30(3), 31-47.

Çetin, Ş. (2009). Reviewing the ideas of the faculty of education students towards academic procrastination behaviors. Gazi University Journal of Industrial Arts Education, 25, 1-7.

Çikrıkçi, Ö., \& Erzen, E. (2016). Gender Differences on Academic Procrastination: Meta-Analysis. Hacettepe Üniversitersity Journal of Education, 31(4), 750-761.

Deniz, M. E., Traş, Z., \& Aydoğan, D. (2009). An investigation of academic procrastination, locus of control, and emotional intelligence. Educational Sciences: Theory \& Practice, 9(2), 607-632.

Erözkan, A. (2004). University student's test anxiety and coping behaviours. Mugla University Journal of Social Sciences and Humanities Research, 12, 13-38.

Gençdoğan, B. (2006). Investigation relationship among anxiety of examination, social support and submission of college students. Journal of Social Sciences Institute, Ataturk University, 7(1), 153-164.

Haycock, L. A., McCarthy, P., \& Skay, C. L. (1998). Procrastination in college students: the role of self-efficacy and anxiety. Journal of Counseling and Development, 76, 317-324.

https://doi.org/10.1002/j.1556-6676.1998.tb02548.x

Hess, B., Sherman, M. F., \& Goodman, M. (2000). Eveningness predicts academic procrastination: the mediating role of Neuroticism. Journal of Social Behavior and Personality, 15, 61-74.

Hussain, I., \& Sultan, S. (2010). Analysis of procrastination among university students. Procedia Social and Behavioral Sciences, 5(2010), 1897-1904. https://doi.org/10.1016/j.sbspro.2010.07.385

Kağan, M. (2009). Determining the variables which explain the behavior of academic procrastination in university students. Ankara University, Journal of Faculty of Educational Sciences, 42(2), 113-128. https://doi.org/10.1501/Egifak_0000001179

Karabıyık, Ç. B., Çavuşoğlu, C., \& Gürol, M. (2015). Investigating of academic procastination levels of the undergraduate students. The Journal of Academic Social Science Studies, 34(2), 385-394.

Karasar, N. (2005). Scientific Research Methods. Ankara: Nobel Publishing.

Khan, M. J., Arif, H., Noor, S., \& Muneer, S. (2014). Academic procrastination among male and female university and college students. FWU Journal of Social Sciences, 8(2), 65-70.

Küçük, D. P. (2010). Assessment of relation between test anxiety, self-esteem and success in instrument for candidates of music teachers. Ahi Evran University Journal of Educational Faculty, 11(3), 37-50.

McCown, W. G., \& Roberts, R. (1994). A Study of academic and work-related dysfunctioning relevant to the college version of an indirect measure of impulsive behavior. Integra Technical Paper 94-98, Radnor, PA: Integra, Inc.

Onwuegbuzie, A. J. (2004) Academic procrastination and statistics anxiety. Assessment \& Evaluation in Higher Education, 29(1), 3-19. https://doi.org/10.1080/0260293042000160384

Özer, A., \& Altun, E. (2011). The reasons for academic procrastination among university students. Mehmet Akif Ersoy University Journal of Education, 21, 45-72.

Özer, B. U., \& Topkaya, N. (2011). Academic procrastination and test anxiety. Adnan Menderes University Education Faculty Journal of Education Sciences, 2(2), 12-19.

Pala, A., Akyıldı, M., \& Bağcı, M. (2011). Academic procrastination behaviour of pre-service teachers' of Celal Bayar University. Procedia - Social and Behavioral Sciences, 29(2011) 1418-1425. https://doi.org/10.1016/j.sbspro.2011.11.381

Saracaloğlu, A. S., \& Gökdaş, İ. (2016).Variables that predict academic procrastination behavior in prospective primary school teachers. Journal of Educational Science Research, 6(1), 43-61. https://doi.org/10.12973/jesr.2016.61.3

Saracaloğlu, A. S., \& Karasakaloğlu, N. (2011). Investigation of the levels of reading comprehension and study and 
learning strategies of primary school teacher candidates according to some variables. Education and Science, 36(361), 98-115.

Senecal, C., Julien, E., \& Guay, F. (2003). Role conflict and academic procrastination: A self-determination perspective. European Journal of Social Psychology, 33, 135-145. https://doi.org/10.1002/ejsp.144

Şirin, E. F. (2011). Academic procrastination among undergraduates attending school of physical education and sports: Role of general procrastination, academic motivation and academic self-efficacy. Educational Research and Reviews, 6(5), 447-455.

Solomon, L. J., \& Rothblum, E. D. (1984). Academic procrastination: frequency and cognitive-behavioral correlates. Journal of Counseling Psychology, 31, 503-509. https://doi.org/10.1037/0022-0167.31.4.503

Spielberger, C. D., \& Vagg, P. R. (1995). Test Anxiety: Theory, assessment, and treatment. Washington D. C.: Taylor \& Francis.

Steel, P., \& Ferrari, J. (2013). Sex, education and procrastination: An epidemiological study of procrastinators' characteristics from a global sample. Electronic Journal of Research in Educational Psychology, 15 (1), $105-125$. https://doi.org/10.1002/per.1851

Tan, C. X., Ang, R. P., Klassen, R. M., Yeo, L. S., Wong, I. Y., \& Huan, V. S. (2008). Correlates of academic procrastination and students' grade goals. Current psychology-Research \& Reviews, 27(2), 135-144. https://doi.org/10.1007/s12144-008-9028-8

Totan, T., \& Yavuz, Y. (2009). Turkish validity and realibility study of Westside text anxiety scale. Mehmet Akif Ersoy University Journal of Education Faculty, 9(17), 95-109.

Uzun, Ö. B. (2009). Academic procrastination behaviors in a group of high school students: their frequency, possible causes, and the role of hope. Journal of Turkish Psychological Counseling and Guidance, 4(32), 12-19.

Uzun, Ö. B., \& Topkaya, N. (2011). Academic procrastination and test anxiety. Adnan Menderes University Journal of Educational Sciences, 2(2), 12-19.

Uzun, Ö. B., Demir, A., \& Ferrari, D. (2009). Exploring academic procrastination among Turkish students: possible gender differences in prevalence and reasons. The Journal of Social Psychology, 149(2), $241-257$. https://doi.org/10.3200/SOCP.149.2.241-257

Yayc1, L., \& Düşmez, İ. (2016). Investigating adolascents' academic procrastination behaviors accoring to some variables. Journal of International Society Researches, 6(10), 82-101.

Yıldırım, İ., \& Ergene, T. (2003). Exam anxiety, submissive behaviors and social support as predictors of the academic achievement of high school seniors. Hacettepe University Journal of Education, 25(25), 224-234.

\section{Copyrights}

Copyright for this article is retained by the author(s), with first publication rights granted to the journal.

This is an open-access article distributed under the terms and conditions of the Creative Commons Attribution license which permits unrestricted use, distribution, and reproduction in any medium, provided the original work is properly cited. 